\title{
Literature Review : Depresi Pada Perawat Dalam Masa Pandemi Covid-19
}

\author{
Benni Surya Darma1*, Hana Nafiah² \\ ${ }^{1,2}$ Program Studi Sarjana Keperawatan, Universitas Muhammadiyah Pekajangan Pekalongan, \\ Indonesia \\ *email : Bennisuryadarma11@gmail.com
}

\begin{abstract}
Depression is one of the psychological disorders that can be experienced by nurses during the covid-19 pandemic. Depression is a mental disorder that often started from untreated stress. It can make the person fall into a phase of depression. To describe the level of depression in nurses during the COVID-19 pandemic. This study was a quantitative study using a literature review. There were 5 articles, searched from Google Scholar and Pubmed published in 2019-2021, analyzed using the Hawker instrument. The results showed that the respondents were female respondents $(99.65 \%)$. There were 61.2 percentage points for respondents aged 18-35 and 68.9 percentage points for unmarried respondents. The depression levels of the respondents were mild depression (37.1\%), normal level depression $(59.5 \%)$, and $(36 \%)$. The depression in nurses during the covid-19 pandemic was caused by their severe psychological disorders, such as increased workloads, exposure to viruses, fear of covid-19 infection. inadequate facilities (PPE).
\end{abstract}

Keywords: Nurse, covid-19, depression

\begin{abstract}
Abstrak
Depresi merupakan salah satu gangguan psikologis yang dapat dialami oleh perawat dalam masa pandemi covid-19. Depresi adalah gangguan mental yang sering terjadi berawal dari stres yang tidak bisa diatasi, maka orang tersebut dapat jatuh ke fase depresi. Mengetahui gambaran tingkat depresi pada perawat dalam masa pandemi covid 19. Penelitian ini adalah penelitian kuantitatif menggunakan literature review 5 artikel dan ditelaah menggunkan instrimen hawker dengan penelusuran elektronik pada Google scholar dan pubmed yang dipublish pada tahun 2019-2021. Hasil dari ke-5 artikel responden yang memiliki presentase paling tinggi adalah responden perempuan $(99.65 \%)$, responden usia $18-35$ tahun $(61.2$ $\%)$, responden belum menikah $(68.9 \%)$. responden depresi yang tertinggi adalah depresi tingkat ringan (37.1\%) depresi tingkat normal mendapatkan (59.5\%) dan (36 \%). Kejadian depresi pada perawat dalam masa pandemi covid 19 terjadi karena perawat mengalami gangguan psikologis yang parah mulai dari peningkatan beban kerja, paparan virus, ketakutan akan tertular covid 19, fasilitas yang tidak memadai (APD).
\end{abstract}

Kata kunci: Perawat; depresi; Covid 19

\section{Pendahuluan}

Pada awal tahun 2020 dunia digemparkan dengan penemuan virus jenis baru yaitu corona virus jenis baru (SARS Cov-2) dan penyakitnya disebut dengan corona virus disaese 19 (Covid 19). Asal mula virus ini berasal dari kota Wuhan, Tiongkok. Virus ini ditemukan pada akhir desember 2019. Corona virus merupakan jenis virus RNA, termasuk family virus corona yang menyebabkan infeksi sistem pernapasan. Virus corona bersifat zoonosis dimana dapat ditularkan dari hewan ke manusia, tapi beberapa bukti telah ditemukan bahwa virus tersebut dapat ditularkan dari manusia ke manusia melalui droplet, kontak dengan droplet dan bahkan melalui penularan fekaloral khususnya virus corona jenis baru ini yaitu SARS-CoV-2 [20]. Virus ini bersifat 


\section{Prosiding Seminar Nasional Kesehatan 2021 Lembaga Penelitian dan Pengabdian Masyarakat Universitas Muhammadiyah Pekajangan Pekalongan}

sensitif terhadap panas dan secara efektif dapat di nonaktifkan dengan pemberian disinfektan yang mengandung klorin, pelarut lipid yang mengandung suhu 56 derajat celcius selama 30 menit[24].

Infeksi virus corona disebabkan oleh virus corona itu sendiri. Kebanyakan virus corona dapat menyebar atau ditularkan secara zoonosis (antara hewan dan manusia) dan dapat menyebabkan gejala ringan hingga berat.Penularan virus ini diperkirakan sama dengan kejadian MERS dan SARS sebelumnya yaitu penularan manusia ke manusia. Penularan lainya dapat melalui droplet yaitu dari percikan-percikan dari hidung dan mulut, kontak dengan droplet dan fekal-oral. Percikan-percikan tersebut akan menempel pada benda dan orang bisa terinfeksi jika menyentuh benda tersebut atau terkontaminasi[8]. Virus Covid 19 dapat bertahan hingga 72 jam pada plastic, kurang dari 24 jam pada karton dan kurang dari 4 jam pada tembaga [20].

Kasus corona virus menurut WHO pada tanggal 2 maret 2020, saat ini ada 65 negara yang terinfeksi virus corona dengan kasus yang terinfeksi 90.308 , dengan angka mortalitas 2,3\% diseluruh dunia. World Health Organization sendiri mengumumkan pandemi ini pada tanggal 11 Maret 2020. Pandemi Covid-19 telah menyebar dengan cepat ke lebih dari 17.660.523 kasus dengan 680.894 kematian yang mempengaruhi 260 negara hingga Agustus 2020. Kasus kematian pertama akibat virus ini adalah pada pasien dengan penyakit penyerta tumor intra abdomen dan kelainan di liver [24]

Di masa pandemi tenaga kesehatan merupakan garda terdepan dalam menangani pandemi COVID 19. Perlu diperhatikan juga bahwa tenaga kesehatan baik dokter, perawat, farmasi maupun tenaga administrasi rumah sakit perlu mendapatkan perlindungan diri yang baik dan terjamin. Tenaga kesehatan rela berjuang untuk merawat dan melayani masyarakat bahkan mempertaruhkan nyawa dan keluarganya demi mencegah penyebaran COVID 19. Tenaga kesehatan adalah orang yang bekerja dibidang kesehatan dimana tenaga kesehatan memiliki keterampilan dan pengetahuan melalui pendidikan di bidang kesehatan untuk melakukan tindakan kesehatan. Di sini, tenaga kesehatan sangat rentan terhadap virus ini karena berpotensi tertular ketika merawat pasien positif COVID 19. Maka dari itu tenaga kesehatan penting untuk menggunakan Alat Pelindung Diri (APD) lengkap apabila berhadapan langsung dengan pasien COVID 19. Kerena merekalah yang menjadi garda terdepan dalam penanganan pasien[22].

Dalam menangani pasien Covid 19 penanganan yang memadai sangat diperlukan untuk mengurangi penyebaran penyakit tersebut. Petugas kesehatan sendiri memiliki peran penting dalam merawat pasien Covid 19. Diantara petugas kesehatan tersebut adalah perawat. Perawat selama masa pandemi Covid 19 ini mendapat tantangan tersendiri untuk melakukan asuhan keperawatan yang prefesional dengan resiko tertular sangat tinggi bahkan menjadi korban akibat virus Covid 19. Khususnya perawat yang ada didalam ruang isolasi. Perawat terlibat dalam dalam penangann pasien Covid 19 harus memiliki keterampilan dan pengetahuan dalam mencegahan dan pengendalian infeksi yang tepat, serta perawat harus mengupdate mengenai perkembangan Covid 19[20]. 


\section{Prosiding Seminar Nasional Kesehatan Lembaga Penelitian dan Pengabdian Masyarakat Universitas Muhammadiyah Pekajangan Pekalongan}

Perawat merupakan profesi kesehatan dengan tuntutan kerja tinggi di rumah sakit. Perawat merupakan bagian yang tidak dapat dipisahkan dari proses kesembuhan pasien, perawat sendiri tidak hanya melakukan rutinitas seperti melakukan pengecekan tekanan darah, suhu atau denyut nadi pasien saja. Perawat tertuju pada reaksi keseluruhan pasien terhadap penyakit yang diaami. Perawat lebih memperhatiakan mengatasi rasa sakit fisik pasien, melepaskan pasien dari penderitaan mental dan menghindari timbulnya komplikasi. Selain itu, perawat memberikan perhatian dengan penuh pengertian yang mencakup mendengarkan dengan rasa sabar yang dirasakan oleh pasien serta memberikan dorongan emosi kepada pasien dan memberikan hiburan[23]

Di masa pandemi perawat harus waspada dan mempersiapkan diri untuk melakukan proses keperawatan. Situasi yang tidak kondusif seperti ini harus segera diatasi agar tidak berakibat buruk pada kesehatan psikologis perawat tersebut. Seiring bertambahnya kasus covid 19 ini ada banyak masalah yang muncul seperti ketakutan akan penularan virus covid 19 dan beban kerja lebih berat, hal tersebut dapat memicu terjadinya gangguang mental, salah satu yang dapat kita jumpai adalah depresi [12].

Depresi merupakan gangguan psikologis yang sering terjadi. Bermula dari stress yang tidak bisa diatasi, karena tidak dapat mengatasi stres tersebut sesorang dapat jatuh ke fase depresi. Orang yang mengalami depresi umumnya mengalami gangguan perasaan yang meliputi keaadan emosi, motivasi, fungsional dan gerak tingkah laku serta kognisi [17].

Penelitan yang dilakukan oleh pouralizadeh [16] di rumah sakit ilmu kedokteran universitas guilan mendapatkan 441 responden perawat dan sebagian besar responden berjenis kelamin perempuan dengan presentase 95.2\%. Angka kejadian depresi pada perawat dalam penelitian ini mencapai $37,4 \%$. Hasil penelitian yang dilakukan di rumah sakit ilmu kedokteran universitas guilan mengatakan bahwa perawat perempuan 4.62 kali lebih mungkin mengalami depresi dibandingkan perawat laki-laki. Penelitian ini mengklasifikasikan tingkat depresi yang dialami perawat selama pandemi covid 19 sebagai berikut. Tidak ada minimal $29.0 \%$, ringan 33,6 \%, sedang 20,0\%, cukup parah $10,7 \%$ dan parah 6,8\%.Perawat memiliki kekhawatiran tinggi dalam masa pandemi covid 19 ini, ketidakpastian durasi dan terutama dapat menularkan penyakit ke anggota keluarga mereka sangatlah tinggi.Banyak penelitian yang menunjukkan gangguan psikologis pada perawat selama pandemi covid 19 ini. Dalam hal ini depresi adalah keadaan emosi negatif dan hambatan psikologis perawat. Penyebaran Covid 19 telah memberikan tekanan berat bagi layanan kesehatan terutama perawat. Namun, selama pandemi Covid-19. Tingkat depresi akibat komplikasi psikologis sangat memprihatinkan, ketersediaan layanan konseling untuk mendorong kesejahteraan mental sangat penting bagi penyedia layanan kesehatan, terutama perawat. Selama wabah Coronavirus, penyebab depresi pada perawat dilaporkan karena prevalensi virus yang lebih tinggi, penularan dari manusia ke manusia, serta tingginya kematian akibat virus ini [16].

Depresi pada perawat dapat disebabkan oleh stres emosional yang berhubungan dengan beban kerja perawat tersebut meningkat, tuntutan dan harapan pasien yang mengakibatkan kelesuan, penurunan tingkat konsentrasi, atau kurangnya motivasi 


\section{Prosiding Seminar Nasional Kesehatan 2021 Lembaga Penelitian dan Pengabdian Masyarakat Universitas Muhammadiyah Pekajangan Pekalongan}

untuk bekerja. Depresi secara negatif mempengaruhi proses biologis, psikologis, dan kognitif individu [6]

\section{Metode}

Penelitian ini adalah penelitian kuantitatif menggunakan literature review 5 artikel dan ditelaah menggunkan instrimen hawker dengan penelusuran elektronik pada Google scholar dan pubmed yang dipublish pada tahun 2019-2021.Data yang digunakan tidak langsung terjun secara langsung, melainkan mengambil data dari penelitian terdahulu yang sudah pernah dilaksanakan. Sumber database yang digunakan dalam penelitian ini yaitu Google Scholar yang berupa artikel.,Peneliti menuliskan kata kunci Depression AND Nursing AND Covid 19 OR Corana Virus Disaese di dapatkan 40.900 artikel, kemudian artikel diidentifikasi sesuai topik dan diberi batasan dari tahun 2019 sampai 2021 didapatkan 40.900 artikel. Kemudian artikel di identifikasi lagi berdasarkan original artikel dan artikel yang menggunakan kuisoner PHQ 9 didapatkan 105 artikel, dan dipilah berdasarkan kriteria inklusi yaitu artikel sesuai dengan topik, artikel dalam bahasa Indonesia maupun bahasa Inggris, berupa original artikel dan artikel dengan kuisoner PHQ 9 sehingga didapatkan 5 artikel dalam bentuk fullext dan format Pdf.

\section{Hasil dan Pembahasan}

\section{Hasil}

Berdasarkan analisa dari depresi pada perawat dalam masa pandemi covid 19 yang di ukur menggunakan kuisoner PatientHealthQuisionare 9. PHQ-9 adalah kuisioner yang membantu dalam skrining, mendiagnosis, memantau, dan mengukur tingkat keparahan depresi. PHQ-9 memiliki sembilan pertanyaan. Setiap pertanyaan memiliki skor 0 - 3 (Tidak sama sekali,Beberapa hari,Lebih dari setengah hari,dan Hampir setiap hari), memberikan skor tingkat keparahan 0 hingga 27. Ada pertanyaaan tambahan pada akhirnya, Merupakan pertanyaan tindak lanjut tanpa skor yang menyaring dan memberikan bobot pada sejauh mana masalah depresi telah memengaruhi tingkat fungsi pada pasien. Total skor PHQ-9 diklasifikasikan menjadi 0 4 Depresi minimal,5 - 9 Depresi ringan,10 - 14 Depresi sedang,15 - 19 Depresi sedang,dan 20 - 27 Depresi parah Ammari [13].Berdasarkan hasil analisa e 5 artikel menggunakan telaah kritis hawker berdasarkan tingkat depresi didapatkan 3 artikel memaparkan hasil tingkat depresi yang sama dan 2 artikel memaparkan hasil tingkat depresi yang berbeda. Yang dapat dilihat dari tabel berikut :

Tabel 3.1 karakteristik berdasarkan tingkat depresi

\begin{tabular}{|c|c|c|c|c|c|c|c|c|c|c|c|c|c|c|}
\hline \multirow{3}{*}{ No } & \multicolumn{2}{|l|}{ Artikel } & \multicolumn{12}{|c|}{ Tingkat depresi } \\
\hline & \multirow[b]{2}{*}{ Penulis } & \multirow[b]{2}{*}{ Tabun } & \multicolumn{2}{|c|}{ Minimal } & \multicolumn{2}{|c|}{ Ringan } & \multicolumn{2}{|c|}{ Sedang } & \multicolumn{2}{|c|}{ cukup parah } & \multicolumn{2}{|c|}{ Parab } & \multicolumn{2}{|c|}{ Jumlah } \\
\hline & & & $F$ & $\%$ & $F$ & $\%$ & $F$ & $\%$ & $\mathrm{~F}$ & $\%$ & $F$ & $\%$ & $F$ & $\%$ \\
\hline 1 & $\begin{array}{l}\text { Moluk } \\
\text { pouralizadeh } \\
\text { et.al }\end{array}$ & 2020 & 128 & 29 & 148 & 33.6 & 88 & 20 & 47 & 10.6 & 30 & 6.8 & 441 & 100 \\
\hline 2 & $\begin{array}{l}\text { N.J Robertss, } \\
\text { et.al }\end{array}$ & 2020 & 94 & 51.9 & 56 & 30.9 & 17 & 9.4 & 9 & 5.0 & 5 & 2.8 & 181 & 100 \\
\hline 3 & $\begin{array}{l}\text { Hee jung } \\
\text { jand, et. al }\end{array}$ & 2021 & 4.872 & 32.9 & 5.540 & 37.4 & 2.598 & 17.5 & 1.266 & 8.5 & 547 & 3.7 & 14.823 & 100 \\
\hline Tot: & al responden & & 5.094 & 33 & 5.744 & 37.1 & 2.703 & 17.6 & 1.322 & 8.6 & 582 & 3.7 & 15.445 & 100 \\
\hline
\end{tabular}




\section{Prosiding Seminar Nasional Kesehatan Lembaga Penelitian dan Pengabdian Masyarakat Universitas Muhammadiyah Pekajangan Pekalongan}

Hasil literature review dari 3.1 artikel pada (tabel 1) karakteristik berdasarkan tingkat depresi pada perawat memaparkan hasil yang sama dan dibagi menjadi lima tingkat yaitu depresi minimal, ringan, sedang, cukup parah dan parah. Responden dengan depresi tingkat ringan mendapatkan presentase paling banyak (37.1\%).

Tabel 3.2 karakteristik berdasarkan tingkat depresi

\begin{tabular}{|c|c|c|c|c|c|c|c|c|c|c|c|c|c|c|}
\hline \multirow{3}{*}{ No } & \multicolumn{2}{|l|}{ Artikel } & \multicolumn{12}{|c|}{ Tingkat depresi } \\
\hline & \multirow{2}{*}{ Penulis } & \multirow{2}{*}{ Tahun } & \multicolumn{2}{|c|}{ Normal } & \multicolumn{2}{|c|}{ Ringan } & \multicolumn{2}{|c|}{ Sedang } & \multicolumn{2}{|c|}{$\begin{array}{l}\text { Cukup } \\
\text { berat }\end{array}$} & \multicolumn{2}{|c|}{ Berat } & \multicolumn{2}{|c|}{ Jumlah } \\
\hline & & & $F$ & $\%$ & $\mathrm{~F}$ & $\%$ & $\mathrm{~F}$ & $\%$ & $\mathrm{~F}$ & $\%$ & $\mathrm{~F}$ & $\%$ & $F$ & $\%$ \\
\hline 1 & $\begin{array}{l}\text { Maha Al } \\
\text { Ammari, } \\
\text { et.al }\end{array}$ & 2020 & 156 & 59.5 & 54 & 20.6 & 32 & 12.2 & 18 & 6.8 & 2 & 0.76 & 262 & 100 \\
\hline Tot & responden & & 156 & 59.5 & 54 & 20.6 & 32 & 12.2 & 18 & 6.8 & 2 & 0.76 & 262 & 100 \\
\hline
\end{tabular}

Hasil literature review artikel pada (tabel 3.2) karakteristik berdasarkan tingkat depresi pada perawat dibagi menjadi lima tingkat yaitu depresi normal, ringan, sedang, cukup parah dan berat. Responden dengan depresi tingkat normal mendapatkan presentase paling banyak (59.5\%).

Tabel 3.3 karakteristik berdasarkan tingkat depresi

\begin{tabular}{|c|c|c|c|c|c|c|c|c|c|c|c|c|c|c|}
\hline \multirow{3}{*}{ No } & \multicolumn{2}{|l|}{ Artikel } & \multicolumn{12}{|c|}{ Tingkat depresi } \\
\hline & \multirow[b]{2}{*}{ Penulis } & \multirow[b]{2}{*}{ Tahun } & \multicolumn{2}{|c|}{ Normal } & \multicolumn{2}{|c|}{ Minimal } & \multicolumn{2}{|c|}{ Ringan } & \multicolumn{2}{|c|}{ Cukup parah } & \multicolumn{2}{|c|}{ Berat } & \multicolumn{2}{|c|}{ Jumlah } \\
\hline & & & $F$ & $\%$ & $F$ & $\%$ & $F$ & $\%$ & $F$ & $\%$ & $F$ & $\%$ & $F$ & $\%$ \\
\hline 1 & $\begin{array}{l}\text { Homeira } \\
\text { vafaei, et.al }\end{array}$ & 2020 & 36 & 36 & 35 & 35 & 17 & 17 & 8 & 8 & 4 & 4 & 100 & 100 \\
\hline Tot & esponden & & 36 & 36 & 35 & 35 & 17 & 17 & 8 & 8 & 4 & 4 & 100 & 100 \\
\hline
\end{tabular}

Hasil literature review artikel pada (table 3.3) karakteristik responden berdasarkan tingkat depresi pada perawat dibagi menjadi lima tingkat yaitu depresi normal, ringan, sedang, cukup parah dan parah. Responden dengan depresi tingkat normal mendapatkan presentase paling banyak (36\%).

\section{Pembahasan}

Depresi merupakan gangguan suasana hati yang menurun. Gangguan ini ditandai dengan perasaan sedih dan perasaan tidak peduli dalam jangka waktu yang lama. Berbeda dengan perasaan sedih yang biasa, gangguan depresi menyababkan orang yanng mengalaminya merasakan perasaan sedih meskipun tidak ada sebab yang jelas [17]. 


\section{Prosiding Seminar Nasional Kesehatan Lembaga Penelitian dan Pengabdian Masyarakat Universitas Muhammadiyah Pekajangan Pekalongan}

Depresi lebih sering terjadi pada perempuan dari pada laki-laki, dikarenakan dari faktor biologis, siklus hidup, hormonal, dan psikososial. Stressor psikososial sendiri dapat memengaruhi terjadinya depresi pada seseorang. Jika stresor psikososial yang dialami oleh seseorang semakin besar kemungkinan sesorang tersebut dapat mengalami depresi semakin besar [5].

Depresi pada perawat dapat disebabkan oleh stres emosional yang berhubungan dengan beban kerja perawat tersebut meningkat, tuntutan dan harapan pasien yang mengakibatkan kelesuan, penurunan tingkat konsentrasi, atau kurangnya motivasi untuk bekerja. Depresi secara negatif mempengaruhi proses biologis, psikologis, dan kognitif individu [6].

Kejadian depresi pada perawat dalam masa pandemi covid 19 dari hasil review artikel didapatkan 3 artikel memaparkan hasil tingkat depresi yang sama dan 2 artikel memaparkan hasil tingkat depresi yang berbeda. Penelitian yang dilakukan oleh Pouralizadeh, et.al [16], N.J Robertss, et.al [17] (2020) dan penelitianJang, et. al [6] jumlah perawat yang mengalami depresi ringan paling banyak dengan presentase (37.1\%). Artikel keempat penelitian yang dilakukan oleh Ammari, et.al [13] perawat dengan depresi tingkat normal mendapatkan presentase paling banyak (59.5 \%). Artikel kelima penelitian yang dilakukan oleh Vafaei, et al [7] perawat dengan depresi tingkat normal mendapatkan presentase paling banyak (36\%). Dari hasil literature review dapat disimpulkan bahwa depresi yang banyak dialami perawat adalah depresi tingkat normal dan ringan, hal ini karenakan perawat tersebut memiliki alat pelindung yang baik dan memadai sehingga membuat perawat tersebut akan merasa lebih tenang dan terlindungi dari virus covid 19.

Selain perawat yang mengalami depresi normal dan ringan mendapatkan presentase paling tinggi. Ada juga perawat yang mengalami depresi parah dan berat. Penelitian yang dilkukan oleh Pouralizadeh, et.al [16], N.J Robertss, et.al [17] dan penelitian Jang, et. Al [7] menunjukan perawat yang mengalami depresi parah (3.7 \%), penelitian yang dilakukan oleh Ammari, et.al [13] perawat yang mengalami depresi berat $(0.76 \%)$ dan penelitian Vafaei, et al [7]perawat yang mengalami depresi berat (4\%). Perawat yang mengalami depresi parah atau berat disebabkan karena perawat tersebut bekerja dirumah sakit yang ditunjuk menjadi rujukan covid 19 dengan peningkatan beban kerja yang tinggi, tidak memiliki akses ke alat pelindung diri yang tidak memadai, beban kerja yang tinggi dan memiliki riwayat penyakit kronis.

Penelitian yang dilakukan olehXiong [8], yaitu status psikologis dan self efficacy perawat dirumah sakit china. Penelitian ini mendapatkan 223 responden perawat dengan angka prevalensi depresi $26.4 \%$. Dalam penelitian ini perawat memiliki tekanan psikologis lebih besar dan beresiko tinggi terkena virus covid 19 yang mengakibatkan perawat tersebut mengalami depresi.

\section{Kesimpulan}

Hasil penelitian literature review menyimpulkan bahwa didapatkan hasil tingkat depresi yang berbeda. Dari analisa ke-3 artikel memaparkan hasil yang sama yaitu minimal, ringan, sedang, cukup parah dan parah dengan hasil depresi ringan paling mendapatkan presentase paling banyak (37.1 \%) dan 2 artikel masing- masing 


\section{Prosiding Seminar Nasional Kesehatan Lembaga Penelitian dan Pengabdian Masyarakat Universitas Muhammadiyah Pekajangan Pekalongan}

memaparkan hasil tingkat depresi yang berbeda dengan hasil depresi normal mendapatkan presentase yang paling banyak yaitu (59.6\%) dan (36 \%).

\section{Referensi}

[1] A. Dirgayunita,"Depresi ; Ciri, Penyebab dan Penangannya,"Journal An Nafs: Kajian dan Penelitian Psiokologi, Volume 1, 2016.

[2] A.Susilo, and et, al,"Coronavirus Disase 2019: Tinjauan Literatur Terkini,"Jurnal Penyakit Dalam Indonesia, Vol 7, No.1, 2020.

[3] E. Prabowo, "Buku Ajar Keperawatan Jiwa," Yogyakarta: Nuha Medika, 2017.

[4] E.Prabowo, "Konsep \& Aplikasi Asuhan Keperawatan Jiwa, "Yogyakarta, 2018.

[5] G. Marella, A. Wahab and C. R. Marchira, "Bullying Verbal Menyebabkan depresi pada remaja SMA di kota Yogyakarta," Berita Journal Masyarakat of Community Medicine and Public Health, 2018.

[6] H. J. Jang and et,al, "Factors Affecting Physical and Mental Fatigue among Female Hospital Nurses: The Korea Nurses' Health Study," MDPI, 2021.

[7] H. Vafaei, and et, al, "Obstetrics Healthcare Providers' Mental Health and Quality of Life During COVID-19 Pandemic:Multicenter Study from Eight Cities in Iran,"Psychology Research and Behavior Management, 2020.

[8] H. Yi. S. Xiong and Y. Lin, "The Psychological Status and Self efficacy of Nurses During COVID 19 Outbreak : A Cross Sectional Survey," The Journal of Health Care Organization, Provision, and Financing, Volume 57, hlm. 1- 6, 2020.

[9] J. Moudy, \&R. A.Syakurah, "Pengetahuan terkait Usaha Pencegahan Coronavirus Disease (COVID-19) di Indonesia," Higea Journal Of Public Health Research And Develpment, Higea 4 (3), 2020.

[10] J. T. Astuti\& Suyanto,"Implikasi Manajemen Keperawatan Dalam Penanganan PasienCorona virus Disaese 19 (Covid 19),"Jurnal OfClinical Medicine, hlm 288 297, 2020.

[11] Kaslam and K. Sulistiani, "Kebijakan Jogo Tonggo Pemerintah Provinsi Jawa Tengah," VOX POPULI, Volume 3, Nomor 1, 2020.

[12] L.Rosyanti and I. Hadi, "Dampak Psikologis dalam Memberikan Perawatan dan Layanan Kesehatan Pasien COVID-19 pada Tenaga Profesional Kesehatan," HIJP: Health Information Jurnal Penelitian,Volume 12, 2020.

[13] M. A. Ammariand et, al, "Hasil Kesehatan Mental Diantara Petugas Kesehatan Selama Covid 19 Di Arab Saudi,"Frontiers In Psikiatri, Volume 11, 2020.

[14] M. Fatimah\& F. I.Nuqul,"Kebahagian ditinjau dari status pernikahan dan kebermaknaan hidup,"Jurnal Psikologi, Volume 14 Nomer 2, 2018. 


\section{Prosiding Seminar Nasional Kesehatan $\mathbf{2 0 2 1}$ Lembaga Penelitian dan Pengabdian Masyarakat Universitas Muhammadiyah Pekajangan Pekalongan}

[15] M. H.Sukur, and et,al, "Penanganan pelayanan kesehatan dimasa pandemi covid 19 dalam perspektif hukum kesehatan," Journal Inico Legis, Volume 1 Nomor 1, 2020.

[16] M.Pouralizadeh and et, al, "Kecemasan dan depresi dan faktor terkait pada perawat rumah sakit ilmu kedokteran Universitas Guilan selama covid 19 : Sebuah studi crosssectional berbasis web." Jurnal Internasional IImu Keperawatan Afrika, 2020.

[17] N.J Robert, and et,al,"Tingkat ketahanan, kecemasan, dan depresi pada perawat yang bekerja di area klinis pernapasan selama pandemi COVID," Elsevier, 2020.

[18] N. L.Lubis, "Depresi Tinjauan Psikologis, "Jakarata: Kencana, 2016.

[19] N.Prastika and et,al, "Cara mengelola pikiran, perasaan dan perilaku agar terbebas dari depresi sepenuhnya melalui pendekatan psikologi," (d. Sari, Ed.) CV.Briliyant Angkasa Jaya, 2021.

[20] R. J. Harahap, "Karakteristik Klinis Penyakit Corona Virus 2019," Jurnal Penelitian Perawat Profesional, Volume 2 Nomor 3, 2020.

[21] Sutejo, "Prinsip dan Praktik Asuhan Kepeawatan Jiwa," Babtul, Yogyakarta: Pustaka Baru Press, 2017.

[22] T.L. Pesulima, and Y.Hetharie, "Perlindungan Hukum TerhadapKeselamatan Kerja Bagi Tenaga Kesehatan Akibat Pandemi Covid-19,"SASI, Volume 26 Nomer 2, 2020.

[23] Y. D. Permatasari and M. S. Utami, "Koping Stres Dan stres pada Perawat di Rumah Sakit JiwaX," Jurnal Pemikiran dan Penelitian psikologi, Vol 23 No 2, hlm $121-136,2018$.

[24] Yuliana, "Corona Virus Disaeses (Covid 19); Sebuah Tinjauan Liiterture." Wellness And Healthy Magazine, Volume 3, Nomor 1, 2020.

[25] Z. Abidin, "Upaya Depresi Secara Islami," KOMUNIKA vol 17, No 1, 2017. 